\title{
CAMELS Model With a Proposed 'S' for the Bank Credit Risk Rating
}

\author{
Emna Damak ${ }^{1}$ \\ ${ }^{1}$ Ecole Supérieure des Sciences Economiques et Commerciales de Tunis, Tunisie \\ Correspondence: Emna Damak, Ecole Supérieure des Sciences Economiques et Commerciales de Tunis, 4 Rue \\ Abou Zakaria El Hafsi, Montfleury 1089, Tunis, Tunisie. Tél: 216-98-589-240. E-mail: emna.damak@ yahoo.fr
}

Received: July 20, 2018

doi:10.5539/ijef.v10n9p69
Accepted: August 10, 2018

Online Published: August 15, 2018

URL: https://doi.org/10.5539/ijef.v10n9p69

\begin{abstract}
The purpose of this article is to adopt the CAMELS model to the bank credit risk rating by using simple indicators from publicly available quantifiable information retrieval from their financial statements. Then, it is to test its empirical validation after completion of its revised methodology in 2012 as response to the sub-prime crisis using the rating 'all-in' of 128 banks rated by Moody's of 29 EMENA countries. We use 'ordered logit' regression for the variable to explain the rating classes and the bootstrap resampling techniques to assess the stability degree of the best model selected with the information criteria's AIC. Under this scheme, the explanatory powers measured by Pseudo $R 2$ of the best model is $56.47 \%$. The results show that the two components: intrinsic credit quality and the support of the environment measured respectively by CAMEL factors and the proposed ' $S$ ' factor determine well the 'all-in' ratings. The sovereign rating of the bank establishment country, the size and the 'stand-alone' rating of the bank are the most relevant variables.
\end{abstract}

Keywords: rating agencies, bank credit risk rating, modeling, CAMELS model, bootstrap

\section{Introduction}

Credit rating plays a particularly important role in the banking sector due to the lack of transparency and problems of information asymmetry by which the banks are deemed (Morgan, 2002; Flannery, Kwan, \& Nimalendran, 2004). These characteristics of the banking sector cause further difficulties in the assessment of the solvency of the banks (Packer \& Tarashev, 2011). They lie primarily in assessments of external support, which will benefit the bank, and systemic risk that will transmit. To address these additional difficulties and improve transparency, complementary ratings (communicated to the public or not) are assigned by Credit Rating Agencies (CRAs) on sector-specific rating scales.

The study of the evolution of methodologies revealed of Bank Credit Risk Rating (BCRR) based on the specific publications of famous CRAs worldwide (Fitchratings, 2011; S\&P's, 2011b; Moody's, 2012d; Damak \& Chichti, 2017) showed that they have become, after the sub-prime crisis, more transparent but also more complex. In addition, the BCRR became dialed on two sets of criteria: the intrinsic credit quality (generating the 'stand-alone' ratings) and the environment support (engendering the rating of 'Support'). These two components are combined to give the 'all-in' ratings on universal long-term scale. The literature on the modeling and forecasting of the BCRR is sparse (Salvador, Pastor, \& De Guevara, 2014) and the 'all-in' ratings began to interest researchers only since 2011, which leaves us the possibility to enrich it.

In light of these findings, assuming that the ratings are consistent with the theoretical micro and macroeconomic foundations, we have tried through this study to answer the following question: what are the factor determinants of the 'all-in' ratings?

Since this question exceeded the exploratory stage, our goal in this work is to surround and analyze the publicly available information to explain, remodel and reconstruct the 'all-in' ratings by simple indicators. Our contribution lies in the following two points: (i) the first is to adopt a model tailored for the 'all-in' rating. In fact, a lot of research (such as Derviz \& Podpiera, 2008 and Yüksel, Dincer, \& Hacioglu, 2015) illustrate the relationship between several financial ratios (classified into CAMELS model factors or not) and BCRR but without separate in the specification between its two components. In addition, this famous model is not fully adapted to the 'all-in' rating so we propose a specific ' $\mathrm{S}$ ' factor for this rating. (ii) the second one consists in the fact that this issue is addressed after the completion of the revision of its methodology in response to one of the most deeply moving crises in the financial world, the sub-prime crisis. This revision aims to take into account some elements emerging 
from the lessons of this crisis (Packer \& Tarashev, 2011) and new developments in the financial sector.

The design of a model "over measure" explaining these ratings allows to identify the determinants of the BCRR useful for banks to know the main specific factors and to open to researchers the path to make comparisons over time and space. The results show that the two components: intrinsic credit quality and the support of the environment measured respectively by CAMEL and Support factors determine well the 'all-in' ratings. The sovereign rating of the country where the bank is domiciled, the size and the 'stand-alone' rating of the bank are largely the most relevant variables to explain them.

The rest of this paper is structured as follows: in the second section, we will present an overview of the review of the theoretical and empirical literature on publicly available quantifiable information determinants of the BCRR. In the third section, we will present the conceptual framework of the 'all-in' rating model and our research hypotheses. The fourth section, we present methodological aspects required to test the validity and robustness of the models. The fifth section, we will analyze the results of empirical validation. And in section 6 , we will finish this work by a few words as a conclusion.

\section{The Literature Review}

The scientific literature that we present focus on the question of defining quantifiable publicly available information of bank credit risk rating assigned by the CRAs. The reduced number of research on modeling and forecasting the BCRR (Salvador et al., 2014) concerned mainly the 'stand-alone' ratings: «Bank Financial Strength Ratings 'BFSR'» of Moody's (Poon, Firth, \& Fung, 1999; Laruccia \& Revoltella, 2000; Peresetsky \& Karminsky, 2011; Ögüt, Doğanay, Ceylan, \& Aktaş, 2012 and Salvador et al., 2014) et «Bank Viability Rating 'BVR'» (previously called "Individual Rating 'IR'") of FitchRatings (Hammer, Kogan, \& Lejeune, 2012 and Salvador et al., 2014). Since 2011, researchers have started to be interested in the 'all-in' ratings (Van Laere \& Baesens, 2011; Bissoondoyal-Bheenick \& Treepongkaruna, 2011; Peresetsky \& Karminsky, 2011; Chen, 2012; Van Laere, Vantieghem, \& Baesens, 2012; Shen, Huang, \& Hasan, 2012; Orsenigo \& Vercellis, 2013; Salvador et al., 2014 and Gogas, Papadimitriou, \& Agrapetidou, 2014). The issuing ratings used by Pagratis and Stringa (2009).

The research has shown that there are two ways to identify the important factors and relevant variables that measure them. The first way is to go from a major set of variables without ranking prior in categories or factors predefined by theoretical and empirical studies to use linear dimensionality reduction techniques (Poon et al., 1999; Laruccia \& Revoltella, 2000; Ögüt et al., 2012; Orsenigo \& Vercellis, 2013) and/or non-linear (Orsenigo \& Vercellis, 2013) and then proceed with the application of different methods of analysis (linear regression, discriminant analysis,...) of the coefficients of the main factors or variables that represent the better.

The second way is to go with a relatively smaller set of variables over factors predefined based on previous studies and use the methods of analysis directly on these variables (Pagratis \& Stringa, 2009; Van Laere \& Baesens, 2011; Bissoondoyal-Bheenick \& Treepongkaruna, 2011; Peresetsky \& Karminsky, 2011; Chen, 2012; Van Laere et al., 2012; Shen et al., 2012; Salvador et al., 2014; Gogas et al., 2014). Some studies have used the stepwise procedure to select the best model (Laruccia \& Revoltella, 2000; Godlewski, 2004; Van Laere \& Baesens, 2011; Van Laere et al., 2012; Distinguin, Hasan, \& Tarazi, 2013; and Gogas et al., 2014).

The unanimous result is that approximately two thirds of the ratings can be expected on the basis of a reduced number of financial and accounting statistics publicly available (Shen et al., 2012). But none of this work has addressed the question of the determinants of the BCRR after the completion of the revision of the methodology in response to one of the most deeply moving crises in the financial world, the sub-prime crisis. Table 1 summarizes a selection of these works with their key results. We are going to highlight those works as we move forward in the presentation of the sections of this work.

\section{Conceptual Framework and Research Hypothesis}

The investigation of the scientific literature and specific documents on CRAs revealed methodologies showed that there are two components to the BCRR (Damak \& Chichti, 2018). The first groups the internal factors for the assessment of the Bank intrinsic credit quality (stand-alone). The second includes the external factors for the assessment of environmental support (supports). The 'all-in' rating (Note 1) represents the resultant of these two components. Since the revision of the methodology has affected these two components, we are led to develop a model to explain this rating, despite the difficulties of modeling reported by FitchRatings (2006). The use of 'stand-alone' rating has limited the study to the factors of intrinsic credit quality without taking into account the support of the environment. 
Table 1. Selected empirical studies on the modeling of the BCRR

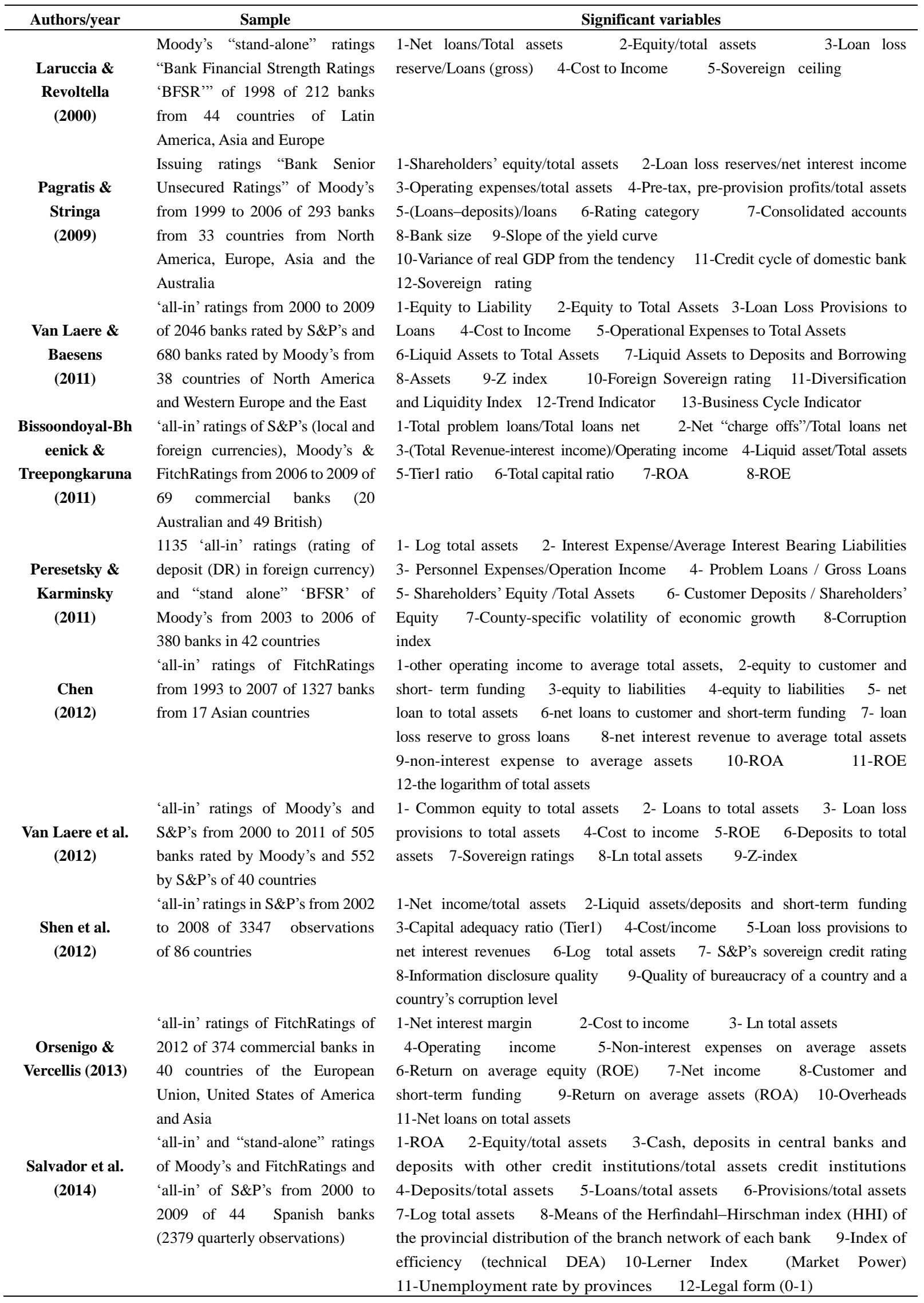




\begin{tabular}{|c|c|c|}
\hline \multirow{6}{*}{$\begin{array}{c}\text { Gogas et al. } \\
(2014)\end{array}$} & \multirow{6}{*}{$\begin{array}{l}\text { 'all-in' Ratings of FitchRatings in } \\
2012 \text { of } 92 \text { banks of the United } \\
\text { States of America }\end{array}$} & 1-Ln total assets in the year $\mathrm{N}-1$ prior to the rating \\
\hline & & 3-LT assets/total assets three year $\mathrm{N}-3$ before the rating \\
\hline & & assets/total assets four year $\mathrm{N}-4$ before the rating \\
\hline & & three years prior 6 -Financial gains or losses from securities as a percentage \\
\hline & & of total interest income four years before the rating \\
\hline & & lagged two years 8-Net operating income lagged two years \\
\hline
\end{tabular}

Source. This table is the construction of the author from the collected studies.

Then, our 'all-in' rating model (1) is as follows:

$$
\text { Rating 'all-in' }=f \text { (intrinsic credit quality of the bank, environment support) }
$$

So our first hypothesis is formulated thus:

$H_{1}$ : The determinants of the 'all-in' rating belong to two components: intrinsic credit quality and environment support.

"The study of these two components includes qualitative/subjective factors and other quantitative/objectives" (Salvador et al., 2014, p. 17). Despite the declarations of the CRAs and the results of previous studies that quantitative measures are only a part of the decision of the bank rating variables, several studies, such as Peresetsky and Karminsky (2011), have shown that models based solely on quantifiable public information can approach the ratings in a reasonable manner. In a first time, we will follow these authors and leave aside the qualitative determinants to focus on the quantitative determinants (Note 2). In subsections 3-1 and 3-2, we define the analytical quantifiable factors of the two components. And in second time in subsection 3-3, we introduce the 'stand-alone' rating generating from the rating process after the analysis of his relation with the 'all-in' rating.

\subsection{Analytical Quantifiable Factors of the Bank Intrinsic Credit Quality (Stand-Alone)}

The study of academic works and of specific documentation dealing with their methodologies revealed by the CRAs before and after revision (Moody's, 1999a, 1999b, 2012d) and the counting of public information on their rating reports show a coherence between the quantitative assessment of the bank's intrinsic credit quality factors and the famous CAMEL model. Since his introduction in the 1980s by the U.S. supervisory authorities as a system of rating for the examination of banking institutions, several researchers have studied and investigated bank's performance using this model (Agyei, 2016). This model is based on five factors of fundamental analysis: Capital, Assets, Management, Earnings and Liquidity; of assessment of the financial health of banks. In 1996, the "Sensitivity to Market Risk" is added as a sixth factor to this model (Yüksel et al., 2015). Derviz and Podpiera (2008) see that the CAMELS model, under its composite and component form, is generally accepted as a monitoring instrument and important research subject for those who are interested in the behavior of the banks for academic or applied purposes. A lot of research, such as Derviz and Podpiera (2008) and Yüksel et al. (2015), illustrate the relationship between several financial ratios (classified into CAMEL(S) model factors or not) and bank credit risk rating but this famous model is not fully adapted to the 'all-in' rating. Therefore, since the BCRR is a relative measure of the credit risk only (without taking into account other banking risk in a separate way), we will ignore this added factor and take the first five factors as the first component of our 'all-in' rating model (Note $3)$.

\subsubsection{Capital (C)}

The capital of the bank is intended to absorb unexpected losses in case of difficulty. Equity protects depositors, creditors and investors against expected losses that would be incurred by them (FitchRatings, 2011). The CRAs are looking to assess the appropriate level of own funds which must be assigned to each trade bank risk: credit risk, market risk, risk of off balance sheet and risk inherent to the nature of the activity. Estrella, Park and Peristiani (2002) showed that the information provided by the bank credit ratings is correlated to those provided by the capital ratios. Several authors (Shen et al., 2012; Salvador et al., 2014; for example) have found that well-capitalized banks have a better probability of getting a high rating.

\subsubsection{Assets (A)}

The quality of the assets refers primarily to performing assets productive of income at the bank, which are essentially formed by the portfolio of securities (market risk) and the portfolio of loans (credit risk), as well as the elements of off-balance sheet (for example: guarantees, letters of credit and the instruments derived). Moody's 
(1999a, 1999b) states that the biggest risk to which the holder of a security issued by a bank is the fact that the institution may suffer from asset quality not recognized problem. Accordingly, a bank with a poor quality of assets is closer to insolvency and is therefore associated with a low rating. Many studies in the literature have stated that banks with better quality of assets tend to acquire a higher rating (Gogas et al., 2014; ...).

\subsubsection{Management (M)}

The quality of the management is the subjective element of the CAMEL model and the most difficult to capture quantitatively. It is the ability of managers to generate the maximum revenue of performing assets available while controlling the expenses of the bank. It spans a wide range of quality characteristics, such as the report cost-efficiency, experience and integrity, reputation and expertise, strategic planning and the ability to maintain an internal and external effective communication, that affect the level of risk and the quality of the income of the bank. Several works (Van Laere et al., 2012; Orsenigo \& Vercellis, 2013; ...) confirmed that efficient banks tend to get high ratings.

\subsubsection{Earnings (E)}

The CRAs consider profitability as the ultimate determinant of the success or failure of an institution and the key factor in the assessment of the quality of credit from a bank. They measure the ability of an institution to create value and to maintain or improve the level of capital by adding to his stock of stable resources. Analysts seek to understand the potential for profits, which protect against the risks inherent in the activity that it performs, in view of its importance for the institution while defending its market positions. More are the bank profits, easier the losses are absorbed and higher should be the rating of bank credit. Almost all of the empirical studies (see table 1) have confirmed this conclusion.

\subsubsection{Liquidity (L)}

The CRAs declare that a liquidity crisis is often the immediate cause of a bank failure while high liquidity can help a fragile institution to ensure its refinancing in difficult times. It is more important in the analysis of weak financial institutions because they are more sensitive to loss of customer confidence and the abrupt withdrawal of funds (Moody's, 1999a, 1999b). Shen et al. (2012) indicated that the ratings increase with the bank liquidity amount and vice versa.

Therefore, our second hypothesis is formulated thus:

\section{$\mathrm{H}_{2}$ : CAMEL factors explain partly the 'all-in' rating.}

\subsection{Analytical Quantifiable Factors of the Environment Support (Supports)}

The second component of the model of the 'all-in' rating is relative to the "support of environment" assessment and represent the 'S' factor that we propose. Indeed, Moody's (2007b, 2007c, 2012d) distinguishes between systemic support (national Government) and not systemic ('parents', group, regional and local government). But in the academic literature on the BCRR determinants, the authors retain support variables (such as sovereign risk and/or bank size) implicit without classified it in specific factors. Packer and Tarashev (2011) stressed the remarkable importance of external support, particularly in the crisis of sub-prime where economic authorities have come to the rescue of some banks in order to prevent their failure.

The empirical works, to our knowledge, that have distinguished the second component of the first (the intrinsic credit quality) explicitly in modeling the 'all-in' rating are those of Peresetsky and Karminsky (2011) and Salvador et al. (2014) but without classification of the variables in the different support sub-factors. We will follow these authors and present them independently of the environment support sub-factors defined by Moody's because of the affiliation measurement variables to more than one factor. Supports variables selected to measure the environment support of the bank are the sovereign rating of the country of the bank, its size, the origin of capital and its activity.

\subsubsection{Sovereign Rating}

Consistent with other ratings, the sovereign rating is the assessment of the ability and the willingness of governments to meet their financial obligations (Al-sakka, Gwilymo, \& Nhung, 2013). Moody's (2012b, p. 1) specifies that "Deterioration in sovereign credit quality can directly affect the credit standing of other issuers domiciled within the sovereign, and, more generally, tends to be associated with macroeconomic and financial market trends that are unfavorable for all issuers".

The introduction of the sovereign rating as a variable to control sovereign credit risk, in the country where the bank is domiciled, is to take account of the potential effects around the country. One of the causes of these effects is the difference in regulation and surveillance investigated among other by Barth, Caprio, and Levine (2004). Aktug, Nayar, and Vasconcellos (2013) showed that the characteristics of the banking sector as the concentration of the 
system, liquidity of assets of banks and size of the financial system are significantly associated with sovereign ratings.

Al-sakka et al. (2013) also showed that degradation of sovereign ratings and negative signals from surveillance in developed European countries during the current debt crisis have important effects on the degradations of the ratings of the banks. These results show that the BCRR are strongly related to the sovereign ratings and the banks located in countries with low ratings of sovereign credit risk tend to have weak BCRR (Hammer et al., 2012; Shen et al., $2012 ; \ldots)$.

$H_{3}$ : A bank with a low sovereign rating of his establishment country tends to have a weak 'all-in' rating.

\subsubsection{Size of the Bank}

McAllister and McManus (1993) stressed that the big banks have better possibilities of diversification of risks and reduction of financing costs than smaller banks. In addition, the existence of economies of scale should allow large banks to benefit from the efficiency gains in cost, but the inherent complexity of the big banks relatively mitigates this effect.

Several studies (Pankoke, 2014; Drehmann \& Tarashev, 2011a, 2011b; Pais \& Stork, 2013; ...) confirmed that the size measures the systemic importance of a banking institution and represents a main determinant confirming the usual argument of "Too Big To Fail 'TBTF". However, Haldane and Madouros (2012) have shown that there is no solid evidence to indicate that major banks are less risky investments, except for the fact that they are too big to be allowed to fail.

The CRAs, on their side, support this principle (Moody's, 2002). In fact, Hau, Langfield and Marques-Ibanez (2013), by examining the quality of the BCRR attributed by the three largest CRAs in 16 countries (United States of America and 15 countries of Europe) between 1990-2011, found that on average, the big banks receive higher ratings which help to perpetuate the existence of the principle of 'TBTF' of banks.

$H_{4}$ : A big bank tends to have a higher 'all-in' rating.

\subsubsection{Origin of Capital}

Iannotta, Nocera and Sironi (2013) showed a significant difference in the risk of default and operating levels in public versus private banks. They point out that public banks have a higher risk of exploitation (measured by the 'stand-alone' rating) but a risk of default (measured by the 'all-in' rating) lower than that of private banks, indicating that the presence of Government support may generate moral hazard and induce a higher risk of operational decision-making. These results find their foundations in several theoretical and empirical works (for example, Demirgüç-Kunt \& Detragiache, 2002; Iannotta et al., 2013). Consistent with these studies, Moody's (1999a, 1999b, 2012d) declares the importance of ownership of the capital to the State for systemic support. Then, the membership of the bank in whole or in part to the State negatively affects the rating 'stand-alone' but positively the 'all-in' rating.

$H_{5}$ : A public bank enjoys a good 'all-in' rating.

\subsubsection{Activity of the Bank}

Van Laere and Baesens (2011) and Chen (2012) have found that if the model of functioning of the bank is not enough diversity, banks will not receive a high rating. Salvador et al. (2014) showed that CRAs punish not diversified banks that concentrate their balance sheet on the credit activity. They state that with the onset of the sub-prime crisis, the small and medium-sized Spanish saving banks were penalized more intensely by the CRAs because of the business model followed by a number of saving banks, based on the credit traditional activity and focused on real estate-related activities. Consistent with these studies, Moody's (1999a, 1999b, 2012d) said the importance of the universality of the bank for the BCRR. Then, we can infer that a universal bank will have more chance of having a best 'all-in' rating.

$H_{6}$ : A universal bank enjoys a good 'all-in' rating.

After the explanation of the different factors and presentation of assumptions related to the validity of the 'all-in' rating model (1), we can write:

$$
\begin{gathered}
\text { Rating 'all-in' }=f(C A M E L, \text { Supports })=f(\text { Capital, Assets, Management, Earnings, Liquidity, Sovereign rating, } \\
\text { size, origin of capital, activity of the bank })
\end{gathered}
$$

\subsection{Relation between the 'All-In' and 'Stand-Alone'Ratings}

As mentioned earlier, the assessment of bank intrinsic credit quality generates 'stand-alone' rating designed by Moody's «Bank Financial Strength Ratings 'BFSR'». This rating content in addition to the quantitative 
determinants the qualitative ones, the confidential information arising from meetings of analysts in CRAs with bank officials and the experienced analyst opinion. Iannotta et al. (2013) have considered it as a measure of exploitation risk of the bank. This rating is a function of micro and macro-economic factors (Moody's, 2007a, 2012d) and the last factor incorporates the ordinary external supports (Note 4) versus the extra-ordinary external supports that are evaluated in the second compound of 'all-in' rating (Packer \& Tarashev, 2011; Damak \& Chichti, 2017). Laruccia and Revoltella (2000) conclude that the 'stand-alone' rating contents more information than the CAMEL variables and just a part of the information content in support variables. Therefore, our last hypothesis is formulated thus:

$H_{7}:$ The 'stand-alone' rating completes the information's about bank credit risk measured by the 'all-in' rating that our CAMEL'S' model do not contain.

Then, after the assumption related to the relation between the 'all-in' and 'stand-alone' ratings, we can write our 'all-in' rating model (2) as follows:

Rating 'all-in' $=f(C A M E L$, Supports, 'Stand-alone' rating $)=f($ Capital, Assets, Management, Earnings, Liquidity, Sovereign rating, size, origin of capital, activity of the bank, 'stand-alone' rating).

Table 2. Variable definitions

\begin{tabular}{|c|c|c|}
\hline $\begin{array}{l}\text { Components 'A-B'/'CAMEL, Supports 'FACTEURS/ } \\
\text { Ratios and definitions }{ }^{1}\end{array}$ & $\begin{array}{l}\text { Expected } \\
\text { sign }\end{array}$ & Previous studies where the variable was found relevant \\
\hline \multicolumn{3}{|l|}{ EXPLANATORY VARIABLES } \\
\hline \multicolumn{3}{|c|}{ A - The quantifiable explanatory variables in the intrinsic credit quality ${ }^{2}(C A M E L)$} \\
\hline \multicolumn{3}{|l|}{ CAPITAL $(C)$} \\
\hline $\begin{array}{l}\text { CPAO/TAA = Common shareholders equity } \% \text { Total } \\
\text { adjusted assets }\end{array}$ & + & $\begin{array}{l}\text { Laruccia \& Revoltella (2000); Pagratis \& Stringa (2009); } \\
\text { Peresetsky \& Karminsky (2011); Van Laere \& Baesens (2011); } \\
\text { Van Laere et al. (2012); Chen (2012); Salvador et al. (2014) }\end{array}$ \\
\hline RTier $1=$ Tier 1 capital ratio & + & $\begin{array}{l}\text { Bissoondoyal-Bheenick \& Treepongkaruna (2011); Shen et al. } \\
\text { (2012) }\end{array}$ \\
\hline \multicolumn{3}{|l|}{$\operatorname{ASSETS}(A)$} \\
\hline$C O N / P M C=$ Net "charge offs" $\%$ Average customer loans & + & Bissoondoyal-Bheenick \& Treepongkaruna(2011) \\
\hline$A N P / E C=$ Non-performing assets $\%$ Total credits $^{3}$ & - & $\begin{array}{l}\text { Bissoondoyal-Bheenick \& Treepongkaruna (2011); Peresetsky \& } \\
\text { Karminsky (2011) }\end{array}$ \\
\hline \multicolumn{3}{|l|}{ MANAGEMENT (M) } \\
\hline$C E / T A A=$ Operating expenses ${ }^{4} \%$ Total adjusted assets & - & Pagratis \& Stringa (2009); Van Laere \& Baesens (2011) \\
\hline $\begin{array}{l}P H I / P N B=\text { Operating non-interest income } \% \text { Operating } \\
\text { income }\end{array}$ & + & Bissoondoyal-Bheenick \& Treepongkaruna (2011) \\
\hline \multicolumn{3}{|l|}{ EARNINGS (E) } \\
\hline$R O A=$ Net income $\%$ Total adjusted assets & + & $\begin{array}{l}\text { Bissoondoyal-Bheenick \& Treepongkaruna (2011); Chen (2012); } \\
\text { Hammer et al. (2012); Shen et al. (2012); Orsenigo \& Vercellis } \\
\text { (2013); Salvador et al. (2014) }\end{array}$ \\
\hline$R O E=$ Net income \% Equity ordinary tangible means & + & $\begin{array}{l}\text { Bissoondoyal-Bheenick \& Treepongkaruna (2011); Van Laere et } \\
\text { al. (2012); Chen (2012); Hammer et al. (2012); Orsenigo \& } \\
\text { Vercellis (2013) }\end{array}$ \\
\hline \multicolumn{3}{|l|}{ LIQUIDITY $(L)$} \\
\hline TPN/TAA $=$ Total Net loans $\%$ Total adjusted assets ${ }^{5}$ & $+/-$ & $\begin{array}{l}\text { Laruccia \& Revoltella (2000); Chen (2012); Van Laere et al. } \\
\text { (2012); Orsenigo \& Vercellis (2013); Salvador et al. (2014) }\end{array}$ \\
\hline$T D / T A A=$ Total deposits $\%$ Total adjusted assets & $+/-$ & Van Laere et al. (2012) ; Salvador et al. (2014) \\
\hline \multicolumn{3}{|c|}{ B - The quantifiable explanatory variables in the environment support (Supports) } \\
\hline $\begin{array}{l}\text { RS M = Moody's sovereign rating of the country of } \\
\text { establishment of the bank }{ }^{7} \text { on the date of rating. }\end{array}$ & + & $\begin{array}{l}\text { Laruccia \& Revoltella (2000); Pagratis \& Stringa (2009); Van } \\
\text { Laere \& Baesens (2011); } \\
\text { Van Laere et al. (2012); Hammer et al. (2012) ; Shen et al. } \\
\text { (2012) }\end{array}$ \\
\hline $\begin{array}{l}\text { LnTAA }=\text { Total adjusted assets from last } 12-31 \text { preceding } \\
\text { the year of rating (natural } \log )^{6}\end{array}$ & + & $\begin{array}{l}\text { Pagratis \& Stringa (2009); Van Laere \& Baesens (2011); } \\
\text { Peresetsky \& Karminsky (2011); Van Laere et al. (2012); Chen } \\
\text { (2012); Shen et al. (2012); Orsenigo \& Vercellis (2013); } \\
\text { Salvador et al. (2014); Gogas et al. (2014) }\end{array}$ \\
\hline
\end{tabular}




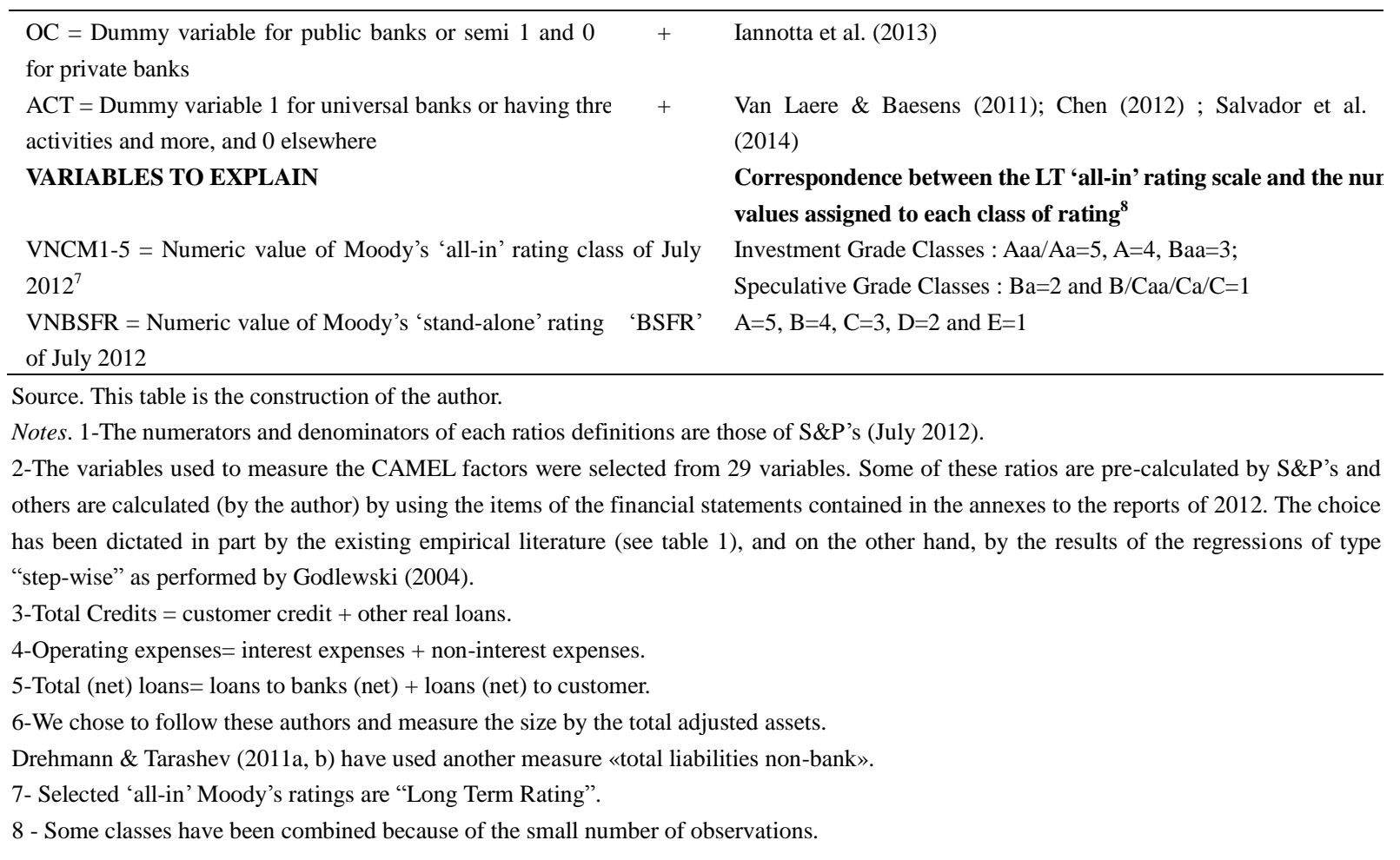

\section{Methodological Aspects}

\subsection{The Explanatory Variables}

We followed Van Laere et al. (2012) and Distinguin et al. (2013) and select more than one variable to represent each CAMEL factor, because the CRAs based on a set of information to assess each factor of solvency of the banks. Each variable found at least one relevant time in previous studies on the determinants of the BCRR. The explanatory variables used, after the recount (Note 5), are presented in Table 2. We also indicate previous empirical work in which each variable has proved to be relevant. All the CAMEL variables of the intrinsic credit quality factors are three-year averages that previous rating year. Our data source is the 'S\&P Capital IQ' database (Note 6).

\subsection{The Variables to Explain}

Our empirical study uses Moody's 'all-in' and 'stand-alone' ratings collected from its website. We chose to conduct the study on the class of rating by making numerical conversions (Note 7) (see Table 2).

\subsection{Sample Characteristics}

We have restricted our sample to the banks of Europe, Middle East and North Africa (EMENA) countries (see Table 3) to control and beyond limited the effect of the heterogeneity of the sample biases that may hide convincing evidence for the validation of our assumptions. The banks of Europe are selected, on the one hand, by the fact that the European region has the highest number of rated banks (Shen et al., 2012). On the other hand, the rating movement adjustment, across the universe, based on the methodologies reviewed in the first half of 2012 has created a large number of changes, primarily downgrade, in the ratings of the banks in the countries of Europe (Packer \& Tarashev, 2011; Moody's, 2012a, 2012c). Over 2075 banks rated by Moody's in 2014, 923 are banks located in EMENA. We collected 332 banks. But only 128 banks of 29 countries were included in the final sample, after the elimination of incomplete records. These are the banks rated by Moody's in July 2012 which have a complete 'stand-alone' account on 'S\&P Capital IQ' database. 
Table 3. Sovereign rating and number of bank by country

\begin{tabular}{|c|c|c|c|c|c|c|c|}
\hline & $\begin{array}{l}\text { List of the } \\
\text { countries }\end{array}$ & $\begin{array}{l}\text { Sovereign rating assigned } \\
\text { by Moody's in } 2012\end{array}$ & $\begin{array}{c}\text { Number of bank } \\
\text { by country }\end{array}$ & & $\begin{array}{l}\text { List of the } \\
\text { countries }\end{array}$ & $\begin{array}{l}\text { Sovereign rating assigned } \\
\text { by Moody's in } 2012\end{array}$ & $\begin{array}{c}\text { Number of bank } \\
\text { by country }\end{array}$ \\
\hline 1 & Austria & Aaа & 1 & 16 & Switzerland & Aaа & 5 \\
\hline 2 & Belgium & $\mathrm{Aa} 3$ & 4 & 17 & Sweden & Aaa & 6 \\
\hline 3 & Denmark & Aaa & 3 & 18 & G-Britain & Aaa & 5 \\
\hline 4 & Finland & Aaa & 1 & 19 & Belarus & B3 & 2 \\
\hline 5 & France & Aaа & 12 & 20 & R-Czech & $\mathrm{A} 1$ & 2 \\
\hline 6 & Germany & Aaa & 11 & 21 & Georgia & $\mathrm{Ba} 3$ & 1 \\
\hline 7 & Greece & $\mathrm{Caa} / \mathrm{Ca} / \mathrm{C}$ & 3 & 22 & Poland & $\mathrm{A} 2$ & 5 \\
\hline 8 & Ireland & Ba1 & 7 & 23 & Russia & Baal & 10 \\
\hline 9 & Italy & $\mathrm{Baa} 2$ & 14 & 24 & Slovenia & $\mathrm{Baa} 2$ & 1 \\
\hline 10 & Liechtenstein & Aaa & 1 & 25 & Turkey & Ba1 & 5 \\
\hline 11 & Luxembourg & Aaa & 1 & 26 & Egypt & B2 & 3 \\
\hline 12 & Netherlands & Aaa & 5 & 27 & Jordan & $\mathrm{Ba} 2$ & 1 \\
\hline 13 & Norway & Aaa & 2 & 28 & Lebanon & B1 & 1 \\
\hline 14 & Portugal & $\mathrm{Ba} 3$ & 3 & 29 & Tunisia & Baa3 & 2 \\
\hline 15 & Spain & Baa3 & 11 & Tota & al des banques & & 128 \\
\hline
\end{tabular}

Source. This table is the construction of the author.

\subsection{Analytical Methods}

After univariate and bivariate descriptive analyses (Note 8), we will follow Laruccia and Revoltella (2000), Peresetsky and Karminsky (2011); and Van Laere and Baesens (2011) and use for our empirical study "ordered logit" regression (Scott \& Freese, 2006) for the variable to explain the numerical value of the rating classes (decreasing scale of 5 to 1 ).

To test the validity of our seven hypotheses, we will run some regressions of 'all-in' or 'stand-alone' ratings (equations from 1 to 10) with differing combinations of variable sets. We will do this in three steps. In the first one, we will run the regressions of the following equations to capture 'all-in' rating quantitative factor determinants and compare their explanatory powers measured by Pseudo $R 2$.

$$
\begin{gathered}
\text { Rating 'all-in' }{ }_{i t}=f(\text { CAMEL })=f\left(A_{i t-1}\right)+\varepsilon_{i t} \\
\text { Rating 'all-in' }{ }_{i t}=f(\text { Supports })=f\left(B_{i t}\right)+\varepsilon_{2 i t} \\
\text { Rating 'all-in' }{ }_{i t}=f\left(\text { CAMEL'S')=f(At-I }+B_{i t}\right)+\varepsilon_{3 i t}
\end{gathered}
$$

In the second step, we will run the regressions of the following equations of 'all-in' ratings using 'stand-alone' rating as an addition explanatory variable. The objective pursued with the introduction of this variable is to determine whether it improves the explanatory power of the 'all-in' rating model. The improvement without causing multicollinearity will be an evidence that the 'stand-alone' rating assessing the bank intrinsic credit quality contains some complementary factors not include in the equations of the first step.

$$
\begin{gathered}
\text { Rating 'all-in' }{ }_{i t}=f(\text { 'Stand-alone' rating })=f\left(V N B S F R_{i t}\right)+\varepsilon_{4 i t} \\
\text { Rating 'all-in' }{ }_{i t}=f(C A M E L \text {, 'Stand-alone' rating })=f\left(A_{i t-1}+V N B S F R_{i t}\right)+\varepsilon_{5 i t} \\
\text { Rating 'all-in' }{ }_{i t}=f(\text { Supports, 'Stand-alone' rating })=f\left(B_{i t}+V N B S F R_{i t}\right)+\varepsilon_{6 i t} \\
\text { Rating 'all-in' }{ }_{i t}=f(C A M E L ' S \text { ', 'Stand-alone' rating })=f\left(A_{i t-l}+B_{i t}+V N B S F R_{i t}\right)+\varepsilon_{7 i t}
\end{gathered}
$$

In the last step and in order to improve the analyses of the relation between these two ratings and our CAMEL'S' model, we also run three regressions of the 'stand-alone' rating with each set of variables and compare their explanatory powers.

$$
\begin{gathered}
\text { 'Stand-alone' } \text { rating }_{i t}=f(\text { CAMEL })=f\left(A_{i t-l}\right)+\varepsilon_{8 i t} \\
\text { 'Stand-alone' rating } i t=f(\text { Supports })=f\left(B_{i t}\right)+\varepsilon_{9 i t} \\
\text { 'Stand-alone' rating }{ }_{i t}=f\left(\text { CAMEL'S') }=f\left(A_{i t-I}+B_{i t}\right)+\varepsilon_{10 i t}\right.
\end{gathered}
$$

Where,

Rating 'all-in' it is the vector of the numeric value of Moody's 'all-in' rating class (with symbol given 'VNCM1-5') of the bank $i$ in the period $t(t=2012)$. 
'Stand-alone' rating it is the vector of the numeric value of Moody's 'stand-alone' rating (with symbol given 'VNBSFR') of the bank $i$ in the period $t(t=2012)$.

$A_{i t-1}$ is the matrix of quantifiable variables (see table 2) for the assessment of the intrinsic credit quality of the bank $i$ in the period $t-1$ preceding the period $t(t=2012)$ of the rating under review.

$\mathrm{B}_{\mathrm{it}}$ is the matrix of quantifiable variables (see table 2) for the evaluation of the environment supports of the bank $\mathrm{i}$ in the period $\mathrm{t}(\mathrm{t}=2012)$ of the rating under review.

$\varepsilon_{\mathrm{pit}}$ are the vectors of the residues of the $\mathrm{p}^{\text {th }}$ equation $(\mathrm{p}=1, \ldots, 10)$. The error term represents the part of the specification error and captures all of the private information that are formed by the confidential information held by Moody's about the bank $\mathrm{i}$ in the period $\mathrm{t}(\mathrm{t}=2012)$ and the interpretation of the expert group in charge of the folder.

For each regression, we will proceed to diagnose the multi-collinearity with the Variance Inflation Factor 'VIF' (Note 9) and to compare the statistic quality with the Akaike Information Criterion 'AIC'(Note 10). And for the two models, we will diagnose the model stability with Bootstrap Inclusion Fractions 'BIF' (Note 11) advocated by Nunez, Steyerberg, \& Nunez, 2011 and will test their predictive powers by calculating the correct classification percentage. And given that the number of observations in our sample is not important for taking a sub-sample; we will test the robustness of our hypotheses by using the bootstrapping approach with 1000 replications (Note 12).

\section{Analysis of Results}

\subsection{Univariate and Bivariate Descriptive Analyses}

The averages for all continuous variables and proportions of the dummy variables calculated using the whole sample of banks, broken down on the five 'all-in' rating classes are presented in table 4 . The frequency (in \%) for the category of investment is $65.62 \%$ (48/128) concentrate in class A (37/128). The increase of: ANP/EC and CE/TAA and the reduction of RS M have perfectly consistent with lower rating classes referred to bad risk. The influence of other variables in the Moody's 'all-in' rating is not clear. The matrix of correlations between the variables in table 5 shows of the Pearson coefficients less than $70 \%$.

Table 4. Descriptive statistics by variable and class of rating

\begin{tabular}{|c|c|c|c|c|c|}
\hline \multirow{2}{*}{$\begin{array}{c}\text { Category of rating } \\
\text { Class of rating }\end{array}$} & \multicolumn{3}{|c|}{ Investment } & \multicolumn{2}{|c|}{ Speculative } \\
\hline & Aaa/Aa & $\mathbf{A}$ & Baa & Ba & $\mathrm{B} / \mathrm{Caa} / \mathrm{Ca} / \mathrm{C}$ \\
\hline Numerical value assigned & 5 & 4 & 3 & 2 & 1 \\
\hline \multicolumn{6}{|c|}{ Sample distributions of 128 banks rated by Moody's in 2012} \\
\hline Frequency & 11 & 37 & 36 & 23 & 21 \\
\hline Frequency in $\%$ & 8.59 & 28.91 & 28.13 & 17.97 & 16.41 \\
\hline Frequency cumulative in $\%$ & 8.59 & 37.50 & 65.63 & 83.60 & 100.00 \\
\hline Frequency par category of rating in $\%$ & \multicolumn{3}{|c|}{65.62} & \multicolumn{2}{|c|}{34.38} \\
\hline \multicolumn{6}{|c|}{ Continuous variables (arithmetic average) } \\
\hline CPAO/TAA & 5.94 & 4.96 & 7.44 & 7.82 & 8.66 \\
\hline RTier1 & 12.25 & 12.00 & 11.02 & 11.32 & 13.04 \\
\hline CON/PMC & 0.14 & 0.22 & 0.32 & 0.12 & 2.73 \\
\hline$A N P / E C$ & 1.41 & 3.68 & 5.44 & 7.97 & 9.56 \\
\hline$C E / T A A$ & 2.50 & 3.71 & 4.05 & 4.12 & 6.98 \\
\hline$P H I / P N B$ & 43.76 & 37.16 & -4.64 & 33.40 & 11.74 \\
\hline ROA & 0.47 & 0.41 & 0.49 & 0.52 & -0.55 \\
\hline ROE & 8.87 & 5.27 & 12.03 & 0.23 & 315.11 \\
\hline TPN/TAA & 49.56 & 52.28 & 65.46 & 62.38 & 55.91 \\
\hline$T D / T A A$ & 52.26 & 48.68 & 57.01 & 57.74 & 66.99 \\
\hline$R S M$ & 17 & 16.27 & 11.61 & 7.78 & 6 \\
\hline $\boldsymbol{T A} \boldsymbol{A}^{I}$ & 250961 & 510185 & 144910 & 51575 & 39288 \\
\hline LnTAA & 11.67 & 12.34 & 10.80 & 10.39 & 9.44 \\
\hline \multicolumn{6}{|l|}{ Dummy variables (sum) } \\
\hline$O C$ & 5 & 8 & 4 & 7 & 7 \\
\hline$A C T$ & 6 & 24 & 17 & 10 & 7 \\
\hline
\end{tabular}

Source. Author' calculation.

Note. 1-Total adjusted asset in thousands of euros. 
Table 5. Matrix of correlations (Coefficient of Pearson)

\begin{tabular}{|c|c|c|c|c|c|c|c|c|c|c|c|c|c|c|}
\hline & СРАОТАА & RTierI & CONPMC & ANPEC & CETAA & PHIPNB & ROA & ROE & TPNTAA & TDTAA & $R S M$ & LnTAA & $O C$ & $A C T$ \\
\hline СРАОТАА & 1.0000 & & & & & & & & & & & & & \\
\hline RTier1 & $0.3890^{*}$ & 1.0000 & & & & & & & & & & & & \\
\hline CONPMC & 0.0774 & 0.0361 & 1.0000 & & & & & & & & & & & \\
\hline ANPEC & 0.0808 & -0.1457 & $0.2696^{*}$ & 1.0000 & & & & & & & & & & \\
\hline CETAA & $0.4035^{*}$ & $0.2048^{*}$ & $0.3689^{*}$ & 0.0495 & 1.0000 & & & & & & & & & \\
\hline PHIPNB & 0.1027 & 0.0036 & 0.0246 & 0.0233 & $-0.2293 *$ & 1.0000 & & & & & & & & \\
\hline$R O A$ & $0.3144^{*}$ & 0.1522 & -0.0008 & $-0.5444^{*}$ & 0.0604 & 0.0789 & 1.0000 & & & & & & & \\
\hline ROE & -0.0910 & -0.1251 & -0.0049 & 0.0117 & 0.0202 & -0.0029 & $-0.1958^{*}$ & 1.0000 & & & & & & \\
\hline TPNTAA & 0.1336 & -0.1170 & -0.0782 & 0.0846 & 0.1639 & -0.0288 & -0.0896 & 0.0352 & 1.0000 & & & & & \\
\hline TDTAA & $0.2714^{*}$ & $-0.2809 *$ & 0.1301 & 0.1692 & $0.2301 *$ & 0.0426 & 0.0583 & 0.1191 & $0.2035^{*}$ & 1.0000 & & & & \\
\hline$R S M$ & $-0.2781 *$ & 0.0526 & -0.1696 & $-0.3923^{*}$ & $-0.2650 *$ & -0.0163 & 0.1698 & $-0.1763 *$ & -0.0805 & $-0.4679 *$ & 1.0000 & & & \\
\hline LnTAA & $-0.6252 *$ & -0.1184 & $-0.1926^{*}$ & $-0.1867^{*}$ & $-0.4205^{*}$ & -0.0407 & -0.1531 & -0.0127 & $-0.2949 *$ & $-0.3860 *$ & $0.4206^{*}$ & 1.0000 & & \\
\hline$O C$ & -0.0892 & 0.0089 & -0.1070 & 0.0708 & -0.0139 & -0.1551 & -0.0984 & -0.0582 & 0.0374 & 0.0281 & -0.0376 & -0.0446 & 1.0000 & \\
\hline$A C T$ & -0.0846 & -0.0186 & -0.0026 & -0.0527 & -0.1350 & 0.1004 & 0.0484 & -0.0831 & $-0.2698^{*}$ & -0.1141 & 0.1518 & $0.3235^{*}$ & 0.0182 & 1.0000 \\
\hline
\end{tabular}

*Significance at $5 \%$.

Source. Author' calculation.

\subsection{Multivariate Analysis}

\subsection{1 'All-In' Rating Quantitative Factor Determinants}

The first results of regressions of 'all-in' ratings are summarized in table 6. The regressions are globally significant (at 1\%) and in general, the estimated coefficients have the expected signs (Note 13). The explanatory power measured by Pseudo $R 2$ of the regressions of the class numerical values to the ten CAMEL variables (column 1, equation 1) and to the four ' $S$ ' Supports variables (column 2, equation 2) are respectively $14.69 \%$ and $37.57 \%$. They allow us to say that the two components of the 'all-in' rating (intrinsic credit quality and the environment supports) have considerable weight in the allocation of this rating but with a large superiority for the second components. Then, the explanatory power of the regression of the class numerical values to the fourteen variables of the two components (column 3, equation 3, model 1) is $50.11 \%$. From these results, we can say that our first hypothesis $H_{l}$ that states, "the determinants of the 'all-in' rating belong to the two components: intrinsic credit quality and support of the environment" is confirmed.

Overall, the model 1 shows that for each factor of the intrinsic credit quality (CAMEL variables), there is at least a relevant variable (exception of 'Earnings' factor) and for the environment supports ('S' variables), two variables were relevant. Specifically, we observe, on the one hand, a positive effect of the adequacy of the capital (measured by CPAO/TAA), Liquidity (measured by TD/TAA) and Supports (measured by RS M and LnTAA) on the probability of being well classed. On the other hand, we observe a negative effect of bad asset quality (measured by ANP/EC and CON/PMC) and the lack of efficiency (measured by CE/TAA). For the 'Earnings' factor, the two explanatory variables present negative (non-expected) coefficients although they are not significant. This result can be explained by a marginal influence of the profitability on 'all-in' rating in 2012 a period characterized by the deep crisis of the European debt one of the consequence of sub-prime crisis.

In addition to the low Pseudo $R 2$ (14.69\%), the regression of the class numerical values of 'all-in' rating to the ten CAMEL variables (column 1, equation 1) presents only two relevant variables (ANP/EC and CE/TAA). With these results, we can say that our hypothesis $H_{2}$ that states, "CAMEL factors explain partly the 'all-in' rating" is confirmed. $H_{3}$ and $H_{4}$ are confirmed too. In fact, the sovereign rating of the bank establishment country and the size of the bank have highly significant (at $1 \%$ ) estimated coefficients with the expected signs. However, $H_{5}$ and $H_{6}$ are infirmed. The non-significance of the capital origin (measured by the dummy variable OC) and the bank activity (measured by the dummy variable ACT) can be explain by our sample characteristics. In fact, they are a low public or semi-public frequency of banks (31/128) and a development level heterogeneity (33/128 developing country banks) in our sample (Note 14).

The sovereign rating and the bank size appear the most relevant variables. Indeed, these variables RSM and LnTAA appear significant coefficients with the original and the bootstrapping with 1000 replications samples. In other words, in addition to their significances at 1\%, their percentages of 'BIF' equal to $100 \%$.

5.2.2 Relation between 'All-In' and 'Stand-Alone' Ratings

The Table 7 summarizes the regressions of 'all-in' ratings using 'stand-alone' rating as an addition explanatory 
variable. The results show that the Pseudo $R 2$ of the regression of 'all-in' rating with the only 'stand-alone' rating variable is over $27 \%$ (column 1). Then, we observe how with the adding of this variable, the explanatory power of each equations increase without causing multicollinearity (columns from 2 to 4 ). In model 2, the 'stand-alone' rating with the sovereign rating, the bank size and Liquidity (measured by TD/TAA) appear the most relevant variables with a coefficient significance at $1 \%$, but only the sovereign rating continues to have a percentage of 'BIF' equal to $100 \%$.

To confirm that the 'stand-alone' rating improves the statistic quality of 'all-in' rating models, we perform the Akaike Information Criterion 'AIC'. The comparison of the results with and without this additional variable show that the AICs in table 7 (with) are lower than the AICs in table 6 (without) for each corresponding equation. This improvement can be explain by the complementary qualitative factors content in 'stand-alone' rating that are eliminated in our quantitative model. Moreover, the confidential information arising from meetings of analysts in CRAs with bank officials, the experienced analyst opinion used to assess the bank intrinsic credit quality and the ordinary external supports emphasis on the macro-economic factors generate the added explanatory power of the regressions with 'stand-alone' rating variable.

In order to improve the analyses of the relation between these two ratings and our CAMEL'S' model, we also run three regressions, presented in table 8, of the 'stand-alone' rating with each set of variables. Our results show that 'stand-alone' rating contents a part of external supports, which confirm Moody's revelations. In fact, in one hand, the Pseudo $R 2$ of 'stand-alone' rating regression with the four support variables is more than $24 \%$. In other hand, the Pseudo $R 2$ of 'stand-alone' rating regression with the fourteen variables is better than the Pseudo $R 2$ of 'stand-alone' rating regression with CAMEL variables (respectively $33.19 \%$ and $12.96 \%$ ). Moreover, the comparison of the results of different equation regressions with 'all-in' rating in table 6 and with 'stand-alone' rating in table 8 shows a superiority of the Pseudo $R 2$ for 'all-in' rating regressions of the same set of variables. These results with those in table 7 allowed us to say that 'stand-alone' rating contents less information about bank credit risk than 'all-in' rating but more than CAMEL variables.

From these results, we can say that our hypothesis $H_{7}$ that states, "the 'stand-alone' rating complete the information's about bank credit risk measured by the 'all-in' rating that our CAMEL'S' model do not contain" is confirmed.

Table 6. The results of equation estimates by OLOGIT of Moody's 'all-in' ratings

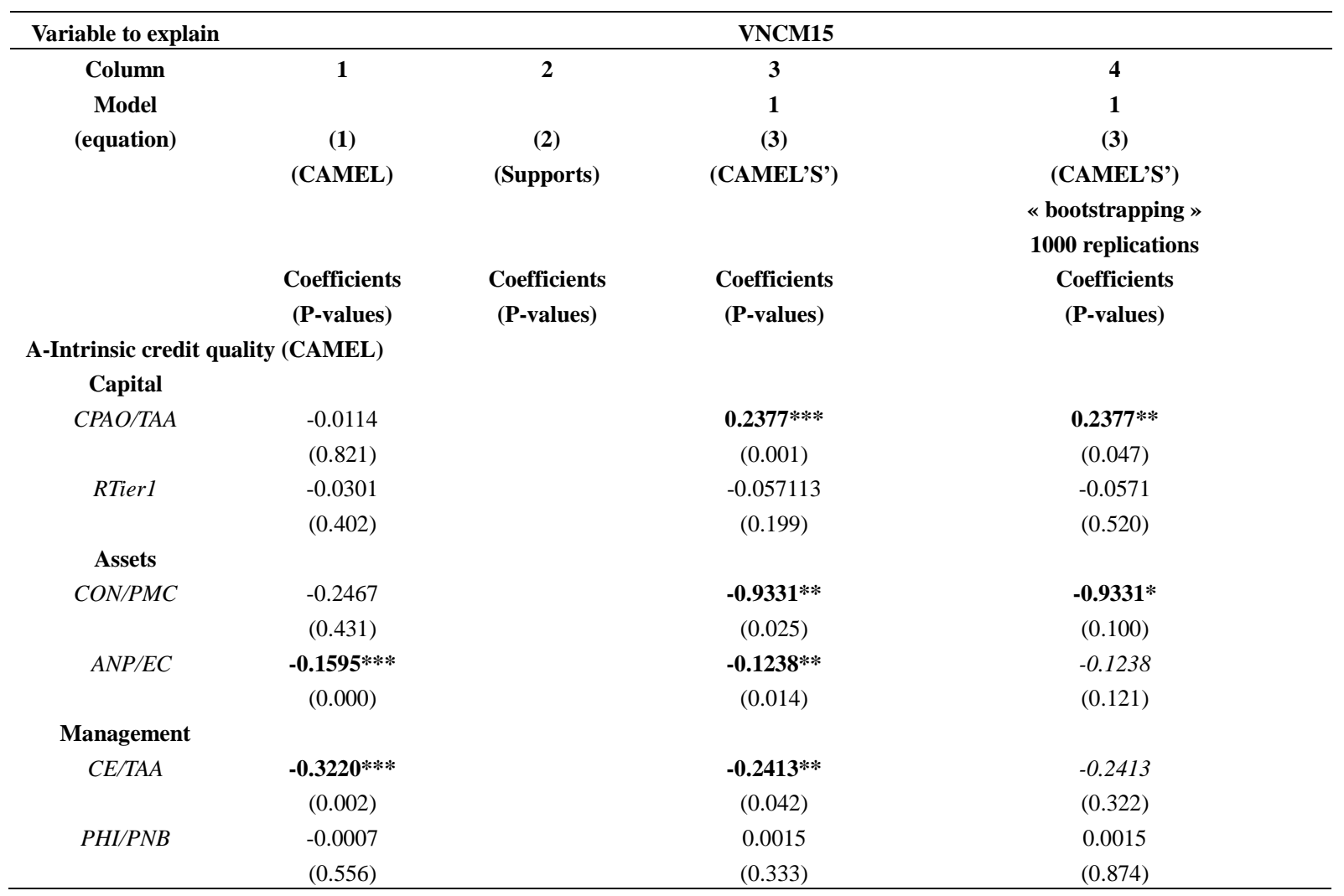




\begin{tabular}{|c|c|c|c|c|}
\hline \multicolumn{5}{|l|}{ Earnings } \\
\hline \multirow[t]{2}{*}{$R O A$} & -0.0438 & & -0.2533 & -0.2533 \\
\hline & $(0.804)$ & & $(0.196)$ & $(0.520)$ \\
\hline \multirow[t]{2}{*}{$R O E$} & -0.0007 & & -0.0045 & -0.0045 \\
\hline & $(0.312)$ & & $(0.386)$ & $(0.699)$ \\
\hline \multicolumn{5}{|l|}{ Liquidity } \\
\hline \multirow[t]{2}{*}{ TPN/TAA } & -0.0059 & & -0.0087 & -0.0087 \\
\hline & $(0.517)$ & & $(0.412)$ & $(0.569)$ \\
\hline \multirow[t]{2}{*}{$T D / T A A$} & -0.0064 & & $0.0492 * * *$ & $0.0492 * *$ \\
\hline & $(0.514)$ & & $(0.000)$ & $(0.026)$ \\
\hline \multicolumn{5}{|c|}{ B-Environment Supports ('S') } \\
\hline \multirow[t]{2}{*}{$R S M$} & & $0.5249 * * *$ & $0.7312 * * *$ & $0.7312 * * *$ \\
\hline & & $(0.000)$ & $(0.000)$ & $(0.000)$ \\
\hline \multirow[t]{2}{*}{ LnTAA } & & $0.5207 * * *$ & $0.9732 * * *$ & $0.9732 * * *$ \\
\hline & & $(0.000)$ & $(0.000)$ & $(0.000)$ \\
\hline \multirow[t]{2}{*}{$O C$} & & 0.3494 & 0.5002 & 0.5002 \\
\hline & & $(0.424)$ & $(0.306)$ & $(0.529)$ \\
\hline \multirow[t]{2}{*}{$A C T$} & & 0.0889 & -0.2113 & -0.2113 \\
\hline & & $(0.812)$ & $(0.622)$ & $(0.704)$ \\
\hline $\mathbf{N}^{\circ}$ of observation & 128 & 128 & 128 & 128 \\
\hline \multicolumn{5}{|c|}{ Diagnosis of the explanatory power } \\
\hline Prob> chi2 2 & 0.0000 & 0.0000 & 0.0000 & 0.0019 \\
\hline Pseudo R2 & 0.1469 & 0.3757 & 0.5011 & 0.5011 \\
\hline \multicolumn{5}{|c|}{ Diagnosis of multi-colinearity $^{I}$} \\
\hline VIF average & 1.54 & 1.17 & 1.65 & \\
\hline VIF Max & 2.02 & 1.33 & 2.62 & \\
\hline \multicolumn{5}{|c|}{ Diagnosis of model stability ${ }^{2}$} \\
\hline \multicolumn{2}{|c|}{ \% BIF min (Vi) 1000 rep. } & & $60.30 \%(\mathrm{ANP} / \mathrm{EC})$ & \\
\hline \multicolumn{2}{|c|}{ \% BIF max (Vi) 1000 rep. } & & $100 \%$ (RS M, LnTAA) & \\
\hline \multicolumn{5}{|c|}{ Diagnosis of information criteria } \\
\hline$A I C$ & 362.4320 & 260.7391 & 231.5736 & \\
\hline
\end{tabular}

*** Significance at 1\%, ** Significance at 5\%, * Significance at $10 \%$.

Source. Author' calculation.

Notes. 1-By calculating the Variance Inflation Factor (VIF).

2-By using the 'Bootstrap Inclusion Fractions 'BIF' test with 1000 replications. The model is even more stable that the BIF minimum is high. The \% BIF min. (Vi) 1000 rep. is the percentage of minimum 'BIF' of the significant variable (vi) with 1000 replications. The \% BIF max (Vi) 1000 rep. is the percentage of maximum 'BIF' of the significant variable (vi) with 1000 replications.

Variable definitions: VNCM15= Numeric value of Moody's 'all-in' rating class of July 2012; VNBSFR= Numeric value of Moody's 'stand-alone' rating 'BSFR' of July 2012; CPAO/TAA= Common shareholders equity \% Total adjusted assets; RTierl= Tier 1 capital ratio; $C O N / P M C=$ Net "charge offs" \% Average customer loans; $A N P / E C=$ Non-performing assets \% Total credits; $C E / T A A=$ Operating expenses $\%$ Total adjusted assets; $P H I / P N B=$ Operating non-interest income $\%$ operating income; RAOAP/TAA= Net operating income before provisions \% Total adjusted assets; $R N / T A A=$ Net income \% Total adjusted assets (ROA); TPN/TAA=Total Net loans \% Total adjusted assets; $T D / T A A=$ Total deposits \% Total adjusted assets; $R S M=$ Moody's sovereign rating of the country of establishment of the bank on the date of rating; $L n T A A=$ Total adjusted assets from last 12-31 preceding the year of rating (natural $\log$ ); $O C=$ Dummy variable for public banks or semi 1 and 0 for private banks; $A C T=$ Dummy variable 1 for universal banks or having three activities and more, and 0 elsewhere.

Table 7. The results of equation estimates by OLOGIT of Moody's 'all-in' ratings with the use of the 'BSFR' ratings

\begin{tabular}{cccccc}
\hline Variable to explain & & \multicolumn{5}{c}{ VNCM15 } \\
\hline $\begin{array}{c}\text { Column } \\
\text { Model } \\
\text { (equation) }\end{array}$ & 1 & 2 & 3 & 4 & 5 \\
& $(4)$ & $(5)$ & $(6)$ & $(7)$ & 2 \\
& & (CAMEL + & (Supports + & (CAMEL'S'+ & (CAMEL'S'+ Stand-alone rating) \\
& (Stand-alone & Stand-alone & Stand-alone & Stand-alone & «bootstrapping » \\
& rating) & rating) & rating) & rating) & 1000 replications \\
& Coefficients & Coefficients & Coefficients & Coefficients & Coefficients \\
& (P-values) & (P-values) & (P-values) & (P-values) & (P-values) \\
\hline
\end{tabular}




\begin{tabular}{|c|c|c|c|c|c|}
\hline \multicolumn{6}{|c|}{ A-Intrinsic credit quality (CAMEL) } \\
\hline \multicolumn{6}{|c|}{ Capital } \\
\hline \multirow{2}{*}{\multicolumn{2}{|c|}{ СРАО/ТАA }} & -0.0610 & & $0.1729 * *$ & 0.1729 \\
\hline & & $(0.292)$ & & $(0.024)$ & $(0.282)$ \\
\hline \multirow[t]{2}{*}{ RTier1 } & & 0.0165 & & -0.0097 & -0.0097 \\
\hline & & $(0.668)$ & & $(0.843)$ & $(0.930)$ \\
\hline \multicolumn{6}{|l|}{ Assets } \\
\hline \multirow[t]{2}{*}{ CON/PMC } & & -0.4175 & & $-0.8414 *$ & -0.8414 \\
\hline & & $(0.248)$ & & $(0.051)$ & $(0.199)$ \\
\hline \multirow[t]{2}{*}{$A N P / E C$} & & $-0.1280 * * *$ & & $-0.1255^{* *}$ & -0.1255 \\
\hline & & $(0.008)$ & & $(0.028)$ & $(0.219)$ \\
\hline \multicolumn{6}{|l|}{ Management } \\
\hline \multirow[t]{2}{*}{ CE/TAA } & & $-0.1719 *$ & & $-0.1998 *$ & -0.1998 \\
\hline & & $(0.060)$ & & $(0.057)$ & $(0.344)$ \\
\hline \multirow[t]{2}{*}{$P H I / P N B$} & & 0.0001 & & 0.0018 & 0.0018 \\
\hline & & $(0.975)$ & & $(0.262)$ & $(0.876)$ \\
\hline \multicolumn{6}{|l|}{ Earnings } \\
\hline \multirow[t]{2}{*}{$R O A$} & & -0.1653 & & $-0.3717 *$ & -0.3717 \\
\hline & & $(0.365)$ & & $(0.089)$ & $(0.449)$ \\
\hline \multirow[t]{2}{*}{$R O E$} & & -0.0005 & & -0.0013 & -0.0013 \\
\hline & & $(0.450)$ & & $(0.838)$ & $(0.926)$ \\
\hline \multicolumn{6}{|l|}{ Liquidity } \\
\hline \multirow[t]{2}{*}{ TPN/TAA } & & -0.0091 & & -0.0082 & -0.0082 \\
\hline & & $(0.359)$ & & $(0.453)$ & $(0.626)$ \\
\hline \multirow[t]{2}{*}{$T D / T A A$} & & 0.0034 & & $0.0466 * * *$ & $0.0466 *$ \\
\hline & & $(0.743)$ & & $(0.001)$ & $(0.051)$ \\
\hline \multicolumn{6}{|c|}{ B-Environment Supports ('S') } \\
\hline \multirow[t]{2}{*}{$R S M$} & & & $0.5158 * * *$ & $0.6796 * * *$ & $0.6796 * * *$ \\
\hline & & & $(0.000)$ & $(0.000)$ & $(0.000)$ \\
\hline \multirow[t]{2}{*}{ LnTAA } & & & $0.4401 * * *$ & $0.8279 * * *$ & $0.8279 * * *$ \\
\hline & & & $(0.002)$ & $(0.000)$ & $(0.010)$ \\
\hline \multirow[t]{2}{*}{$O C$} & & & $0.8423 * *$ & 0.8363 & 0.8363 \\
\hline & & & $(0.066)$ & $(0.108)$ & $(0.304)$ \\
\hline \multirow{2}{*}{\multicolumn{2}{|c|}{$A C T$}} & & -0.0171 & -0.2690 & -0.2690 \\
\hline & & & $(0.966)$ & $(0.550)$ & $(0.650)$ \\
\hline C-Stand-alone ratin & & & & & \\
\hline VNBSFR & $2.9524 * * *$ & $2.7953 * * *$ & $2.4471 * * *$ & $2.1115 * * *$ & $2.1115 * * *$ \\
\hline & $(0.000)$ & $(0.000)$ & $(0.000)$ & $(0.000)$ & $(0.004)$ \\
\hline $\mathbf{N}^{\circ}$ of observation & 128 & 128 & 128 & 128 & 128 \\
\hline Diagnosis of the exp & tory power & & & & \\
\hline Prob> chi2 & 0.0000 & 0.0000 & 0.0000 & 0.0000 & 0.0990 \\
\hline Pseudo R2 & 0.2715 & 0.3407 & 0.4891 & 0.5647 & 0.5647 \\
\hline Diagnosis of multi-c & earity $^{1}$ & & & & \\
\hline VIF average & & 1.54 & 1.39 & 1.76 & \\
\hline VIF Max & & 2.07 & 1.73 & 2.67 & \\
\hline Diagnosis of models & lity $^{2}$ & & & & \\
\hline$\%$ BIF min (Vi) 100 & & & & $36.10 \%$ (ROA) & \\
\hline$\%$ BIF max (Vi) 100 & & & & $100 \%(\mathrm{RS} \mathrm{M})$ & \\
\hline Diagnosis of inform & criteria & & & & \\
\hline AIC & 295.62 & 288.4739 & 218.2892 & 208.6716 & \\
\hline
\end{tabular}

*** Significance at 1\%,** Significance at 5\%, * Significance at $10 \%$.

Source. Author' calculation

Notes. 1-By calculating the Variance Inflation Factor (VIF).

2-By using the 'Bootstrap Inclusion Fractions 'BIF' ' test with 1000 replications. The model is even more stable that the BIF minimum is high. The \% BIF min. (Vi) 1000 rep. is the percentage of minimum 'BIF' of the significant variable (vi) with 1000 replications. The $\%$ BIF $\max (\mathrm{Vi}) 1000$ rep. is the percentage of maximum 'BIF' of the significant variable (vi) with 1000 replications. 
Table 8. The results of equation estimates by OLOGIT of Moody's 'BSFR' ratings

\begin{tabular}{|c|c|c|c|}
\hline Variable to explain & & VNBSFR & \\
\hline Column & 1 & 2 & 3 \\
\hline \multirow[t]{4}{*}{ (equation) } & (8) & (9) & (10) \\
\hline & (CAMEL) & (Supports) & (CAMEL'S') \\
\hline & Coefficients & Coefficients & Coefficients \\
\hline & (P-values) & (P-values) & (P-values) \\
\hline \multicolumn{4}{|c|}{ A-Intrinsic credit quality (CAMEL) } \\
\hline \multicolumn{4}{|l|}{ Capital } \\
\hline \multirow[t]{2}{*}{ СРАО/ТАA } & 0.0493 & & $0.2119 * * *$ \\
\hline & $(0.379)$ & & $(0.003)$ \\
\hline \multirow[t]{2}{*}{ RTier 1} & -0.0525 & & $-0.0717 *$ \\
\hline & $(0.190)$ & & $(0.094)$ \\
\hline \multicolumn{4}{|l|}{ Assets } \\
\hline \multirow[t]{2}{*}{ CON/PMC } & -0.1112 & & -0.3783 \\
\hline & $(0.558)$ & & $(0.297)$ \\
\hline \multirow{2}{*}{$A N P / E C$} & $-0.1205 * * *$ & & -0.0538 \\
\hline & $(0.006)$ & & $(0.260)$ \\
\hline \multicolumn{4}{|l|}{ Management } \\
\hline \multirow{2}{*}{$C E / T A A$} & $-0.2439 * *$ & & -0.1058 \\
\hline & $(0.017)$ & & $(0.310)$ \\
\hline \multirow[t]{2}{*}{$P H I / P N B$} & -0.0004 & & 0.0003 \\
\hline & $(0.718)$ & & $(0.841)$ \\
\hline \multicolumn{4}{|l|}{ Earnings } \\
\hline \multirow[t]{2}{*}{$R O A$} & 0.0376 & & 0.0954 \\
\hline & $(0.829)$ & & $(0.621)$ \\
\hline \multirow[t]{2}{*}{$R O E$} & -0.0007 & & -0.0062 \\
\hline & $(0.577)$ & & $(0.241)$ \\
\hline \multicolumn{4}{|l|}{ Liquidity } \\
\hline \multirow[t]{2}{*}{ TPN/TAA } & 0.0010 & & 0.0036 \\
\hline & $(0.910)$ & & $(0.740)$ \\
\hline \multirow[t]{2}{*}{$T D / T A A$} & -0.0106 & & 0.0155 \\
\hline & $(0.293)$ & & $(0.195)$ \\
\hline \multicolumn{4}{|c|}{ B-Environment Supports ('S') } \\
\hline \multirow[t]{2}{*}{$R S M$} & & $0.2664 * * *$ & $0.3108 * * *$ \\
\hline & & $(0.000)$ & $(0.000)$ \\
\hline \multirow[t]{2}{*}{ LnTAA } & & $0.3066 * *$ & $0.6582 * * *$ \\
\hline & & $(0.015)$ & $(0.000)$ \\
\hline \multirow[t]{2}{*}{$O C$} & & -0.5020 & -0.4496 \\
\hline & & $(0.240)$ & $(0.330)$ \\
\hline \multirow[t]{2}{*}{$A C T$} & & 0.1598 & -0.1636 \\
\hline & & $(0.674)$ & $(0.703)$ \\
\hline $\mathbf{N}^{\circ}$ of observation & 128 & 128 & 128 \\
\hline Diagnosis of the explan & & & \\
\hline Prob> chi2 & 0.0001 & 0.0000 & 0.0000 \\
\hline Pseudo R2 & 0.1296 & 0.2421 & 0.3319 \\
\hline Diagnosis of multi-coli & & & \\
\hline VIF average & 1.54 & 1.17 & 1.65 \\
\hline VIF Max & 2.02 & 1.33 & 2.62 \\
\hline Diagnosis of informatic & & & \\
\hline$A I C$ & 261.1591 & 218.4935 & 214.0473 \\
\hline
\end{tabular}

*** Significance at $1 \%, * *$ Significance at 5\%, $*$ Significance at $10 \%$.

Source. Author' calculation.

Note. 1-By calculating the Variance Inflation Factor (VIF). 


\subsection{Robustness Check}

\subsubsection{Use of Confusion Matrices to Measure the Predictive Powers of the Models}

The results, summarized in tables 9 and 10, show a higher predictive power (correct classification percentage) for model 2, presented in table 7 column 4 . Indeed, the percentage of correct classification is $74.22 \%(95 / 128)$ for this model compared to $64.06 \%(82 / 128)$ for model 1, presented in table 6 column 3 .

Table 9. Matrix of confusion by classes using the 'CAMEL'S" model of the 'all-in' rating

\begin{tabular}{|c|c|c|c|c|c|c|c|}
\hline & Provided class & $A a a / A a$ & $A$ & Baa & $B a$ & $\mathrm{~B} / \mathrm{Ca} / \mathrm{Ca} / \mathrm{C}$ & \\
\hline Actual classe & $V N C$ & 5 & 4 & 3 & 2 & 1 & \\
\hline$A a a / A a$ & 5 & 2 & 8 & 1 & 0 & 0 & 11 \\
\hline$A$ & 4 & 2 & 28 & 7 & 0 & 0 & 37 \\
\hline Baa & 3 & 0 & 5 & 24 & 7 & 0 & 36 \\
\hline$B a$ & 2 & 0 & 0 & 4 & 15 & 4 & 23 \\
\hline \multirow[t]{2}{*}{$\mathrm{B} / \mathrm{Ca} a / \mathrm{Ca} / \mathrm{C}$} & 1 & 0 & 0 & 1 & 7 & 13 & 21 \\
\hline & & 4 & 41 & 37 & 29 & 17 & 128 \\
\hline
\end{tabular}

Source. Author' calculation.

Table 10. Matrix of confusion by classes using the 'CAMEL'S' + Stand-alone rating' model of the 'all-in' rating

\begin{tabular}{|c|c|c|c|c|c|c|c|}
\hline & Provided class & $A a a / A a$ & $A$ & Baa & $B a$ & $\mathrm{~B} / \mathrm{Caa} / \mathrm{Ca} / \mathrm{C}$ & \\
\hline Actual classe & $V N C$ & 5 & 4 & 3 & 2 & 1 & \\
\hline$A a a / A a$ & 5 & 5 & 6 & 0 & 0 & 0 & 11 \\
\hline$A$ & 4 & 1 & 33 & 3 & 0 & 0 & 37 \\
\hline Baa & 3 & 0 & 6 & 25 & 5 & 0 & 36 \\
\hline$B a$ & 2 & 0 & 0 & 5 & 15 & 3 & 23 \\
\hline \multirow[t]{2}{*}{$\mathrm{B} / \mathrm{Caa} / \mathrm{Ca} / \mathrm{C}$} & 1 & 0 & 0 & 0 & 4 & 17 & 21 \\
\hline & & 6 & 45 & 33 & 24 & 20 & 128 \\
\hline
\end{tabular}

Source. Author' calculation.

\subsubsection{Use of the Bootstrapping Approach to Test the Robustness of the Models}

The results with the Bootstrapping approach show that not all the variables maintain their significance. For model 2 (table 7, column 5), only Liquidity factor (measured by TD/TAA), two 'S' variables (RS M and LnTAA) and the 'stand-alone' rating remained relevant. For model 1 (table 6, column 4), we find, with the Liquidity and the two 'S' variables, Capital and Assets respectively measured by CPAO/TAA and CON/PMC as remained significant variables. Overall, the results with the approach 'Bootstrapping' confirm the most of the results with the original sample and of ours hypotheses. In addition, despite the loss of significance of some variables, theirs minimum BIF of significant variables with 1000 replications are higher than $60.30 \%$ (for the variable ANP/EC in the model 1) and $36.10 \%$ (for the variable ROA in the model 2).

\section{Conclusion}

This paper contributes to the existing literature by focusing on the factor determinants of the 'all-in' rating after completion of the BCRR methodology revision in response to the sub-prime crisis. The results are consistent with those of previous theoretical and empirical studies. They confirm that the intrinsic credit quality and support of the environment measured respectively by CAMEL and proposed ' $\mathrm{S}$ ' factors explain well the 'all-in' rating. It is even higher as the sovereign rating of the country of the bank and its size are. In addition, the capital adequacy and good quality of the assets, the liquidity of the bank and the management are positive factor influences. The profitability is also a relatively important factor for the attribution of the rating 'all-in' but it appears to have a not expected negative influence that can be explained by the characteristics of the sample and the period of the study. The sovereign rating of the bank establishment country, the size and the 'stand-alone' rating of the bank are the most relevant variables. The 'stand-alone' rating contents less information about bank credit risk than 'all-in' rating, but more than CAMEL variables and incorporate a part of the external support information. 
At the end of this work, we can conclude that although we have tried to contribute to the existing literature, this research work cannot hide the existence of certain limits. Indeed, because of the non-availability of the data, we have excluded some explanatory variables, considered relevant by CRAs in the BCRR allocation, including variables related to the credit quality of potential supporters of the bank in case of difficulties including the shareholders and the members of the group. In addition, we restricted our sample to the banks of the EMENA; samples from other regions could complement more analysis.

The modeling of the bank credit risk rating, the findings and limitations mentioned can open new horizons in potential areas of investigation that could be the subject of subsequent research.

\section{References}

Aktug, E., Nayar, N., \& Vasconcellos, G. M. (2013). Is sovereign risk related to the banking sector? Global Finance Journal, 24, 222-249. https://doi.org/10.1016/j.gfj.2013.10.001

Al-sakka, R., Gwilymo, A. P., \& Nhung, V. U. T. (2013). Bank and sovereign credit ratings during the European debt crisis. Working Paper, Bangor Business School, Bangor University, UK. Retrieved from http://www.efmaefm.org/0efmameetings/efma\%20annual\%20meetings/2013-Reading/papers/Alsakka-R.pd $\mathrm{f}$

Barth, J., Caprio G., \& Levine, R. (2004). Bank regulation and supervision: What works best? Journal of Financial Intermediation, 13, 205-248. https://doi.org/10.1016/j.jfi.2003.06.002

Bissoondoyal-Bheenick, E., \& Treepongkaruna, S. (2011). An Analysis of the Determinants of Bank Ratings: Comparison across Ratings Agencies. Australian Journal of Management, 36(3), 405-424. https://doi.org/10.1177/0312896211426676

Chen, Y. S. (2012). Classifying credit ratings for Asian banks using integrating feature and the CPDA-based rough sets approach. Knowledge-Based Systems, 26, 259-270. https://doi.org/10.1016/j.knosys.2011.08.021

Damak, E., \& Chichti, J. (2017). L'évolution des méthodologies révélées de la notation du risque du crédit bancaire. Banque \& Stratégie, 356, Mars. Retrieved from http://www.revue-banque.fr/banque-investissement-marches-gestion-actifs/article/evolution-des methodologies-revelees-

Damak, E., \& Chichti, J. (2018). Modélisation de la notation du risque de crédit bancaire après la révision de sa méthodologie en réponse à la crise des subprimes. Papier présenté au Colloque International organisé par 'ASTURIMA', 29, 30 Avril et 01 Mai, Hammamet-Tunisie.

Demirgüç-Kunt, A., \& Detragiache, E. (2002). Does deposit insurance increase banking system stability? An empirical investigation. Journal of Monetary Economics, 49(7), 1373-1406. https://doi.org/10.1016/S0304-3932(02)00171-X

Derviz, A., \& Podpiera, J. (2008). Predicting Bank CAMELS and S\&P Ratings: The Case of the Czech Republic. Emerging Markets Finance \& Trade, 44(1), 117-130. https://doi.org/10.2753/REE1540-496X440107

Distinguin, I., Hasan, I., \& Tarazi, A. (2013). Predicting rating changes for banks: How accurate are accounting and stock market indicators? Annals of Finance, 9, 471-500. https://doi.org/10.1007/s10436-012-0195-0

Drehmann, M., \& Tarashev, N. (2011a). Measuring the systemic importance of interconnected banks. BIS Working Papers, 342. Retrieved from http://www.bis.org/publ/work342.pdf

Drehmann, M., \& Tarashev, N. (2011b). Systemic importance: some simple indicators. BIS Quarterly Review, March. Retrieved from http://ssrn.com/abstract=1785264

Estrella, A., Park, S., \& Peristiani, S. (2002). Capital Ratios and Credit Ratings as Predictors of Bank Failures. Working Paper, Federal Reserve Bank of New York, June. Retrieved from http://citeseerx.ist.psu.edu/viewdoc/download? doi=10.1.1.197.6935\&rep= rep1\&type=pdf

Fitchratings. (2006). The role of support and joint probability analysis in bank ratings. Fitch Report. Retrieved from http://www.fitchratings.com

Fitchratings. (2011). Global Financial Institutions Rating Criteria. Global Financial Institutions Rating Criteria, Master Criteria, 16 August. Retrieved from http://www.fitchratings.com

Flannery, M. J., Kwan, S. H., \& Nimalendran, M. (2004). Market evidence on the opaqueness of banking firms' assets. Journal of Financial Economics, 71, 419-60. https://doi.org/10.1016/S0304-405X(03)00185-5

Godlewski, C. (2004). Influence des facteurs institutionnels sur l'excès de risque et les ratings de banques dans 
les pays émergents. Working Paper, LaRGE, Université Robert Schuman. Retrieved from http://econwpa.repec.org/eps/fin/ papers/0409/ 0409025.pdf

Gogas, P., Papadimitriou, T., \& Agrapetidou, A. (2014). Forecasting Bank Credit Ratings. The Journal of Risk Finance, 15(2), 195-209. https://doi.org/10.1108/JRF-11-2013-0076

Haldane, A., \& Madouros, V. (2012). The dog and the frisbee. Paper, Federal Bank of Kansas Economic Policy Symposium, Wyoming, 31 August, 22-25. Retrieved from http://www.bankofengland.co.uk/publications/Pages/speeches/ 2012/596.aspx

Hammer, P. L., Kogan, A., \& Lejeune, M. A. (2012). A logical analysis of banks' financial strength ratings. Expert Systems with Applications, 39(9), 7808-7821. https://doi.org/10.1016/j.eswa.2012.01.087

Hau, H., Langfield, S., \& Marques-Ibanez, D. (2013). Bank ratings: what determines their quality? Economic Policy, April, 289-333. https://doi.org/10.1111/1468-0327.12009

Iannotta, G., Nocera, G., \& Sironi, A. (2013). The impact of government ownership on bank risk. Journal of Financial Intermediation, 22, 152-176. https://doi.org/10.1016/j.jfi.2012.11.002

Laruccia, E., \& Revoltella, D. (2000). Banking system stability in developing and transition economies: An analysis of the determinants of Moody's bank financial strength rating. Working Paper, R2000-1, Banca Commercial eltalianar Retrieved from http://www.group.intesasanpaolo.com/portalIsir0/isInvestor/PDF_studi_eng/2000_01.pdf

McAllister, P. H., \& McManus, D. (1993). Resolving the scale efficiency puzzle in banking. Journal Banking Finance, 17(2-3), 389-405. https://doi.org/10.1016/0378-4266(93)90039-G

Moody's Investors Service. (1999a). Risque de crédit bancaire - Cadre d'analyse des établissements bancaires dans les pays développés. Méthodologie de Notation, Avril. Retrieved from http://www.moodys.com

Moody's Investors Service. (1999b). Bank credit risk in emerging markets -- An Analytical Framework. Rating Methodology, July. Retrieved from http://www.moodys.com

Moody's Investors Service. (2002). Ratios and US bank ratings. Rating Methodology, December. Retrieved from http://www.moodys.com

Moody's Investors Service. (2007a). Notation BFSR de solidité financière des banques: Méthodologie globale. Méthodologie de Notation, Février. Retrieved from http://www.moodys.com

Moody's Investors Service. (2007b). Incorporation of joint-default analysis into Moody's bank rating methodology. Rating methodology, February. Retrieved from http://www.moodys.com

Moody's Investors Service. (2007c). Incorporation of joint-default analysis into Moody's bank ratings: A refined methodology. Rating Methodology, March. Retrieved from http://www.moodys.com

Moody's Investors Service. (2012a). Moody's global bank ratings likely to decline in 2012. Announcement, Global Credit Research - 19 Jan. Retrieved from http://www.moodys.com

Moody's Investors Service. (2012b). How sovereign credit quality may affect other ratings. Rating Implementation Guidance, Feb. 13. Retrieved from http://www.moodys.com

Moody's Investors Service. (2012c). Moody's reviews ratings for Europeans banks. Rating Action, Global Credit Research, 15 Feb. Retrieved from http://www.moodys.com

Moody's Investors Service. (2012d). Incorporation of Joint-Default Analysis into Moody's Bank Ratings: Global Methodology. Rating Methodology, March 30. Retrieved from http://www.moodys.com

Moody's Investors Service. (2015). Rating Methodology: Banks. March 16. Retrieved from http://www.moodys.com

Morgan, D. (2002). Rating banks: Risk and uncertainty in an opaque industry. American Economic Review, 92, 874-88. https://doi.org/10.1257/00028280260344506

Nunez, E., Steyerberg, W. E., \& Nunez, J. (2011). Regression modeling strategies. Sociedad Espanola de Cardiologia, 64(6), 501-507. https://doi.org/10.1016/j.rec.2011.01.017

Ögüt, H., Doğanay, M. M., Ceylan, N. B., \& Aktaş, R. (2012). Prediction of bank financial strength ratings: The case of Turkey. Economic Modelling, 29(3), 632-640. https://doi.org/10.1016/j.econmod.2012.01.010

Orsenigo, C., \& Vercellis, C. (2013). Linear versus nonlinear dimensionality reduction for banks' credit rating prediction. Journal Knowledge-Based Systems, 47, 14-22. https://doi.org/10.1016/j.knosys.2013.03.001 
Packer, F., \& Tarashev, N. (2011). Rating methodologies for banks. BIS Quarterly Review, June, 39-52. Retrieved from http://www.bis.org/ publ/qtrpdf/r_qt1106f.pdf

Pagratis, S., \& Stringa, M. (2009). Modeling bank senior unsecured ratings: A reasoned structured approach to bank credit assessment. International Journal of Central Banking, 5(2), 1-39. Retrieved from http://ideas.repec.org/a/ijc/ijcjou/y2009q2a1.html

Pais, P., \& Stork, P. A. (2013). Bank size and systemic risk. European Financial Management, 19(3), 429-451. https://doi.org/10.1111/j.1468-036X.2010.00603.x

Pankoke, D. (2014). Sophisticated vs. simple systemic risk measures. Working Paper on Risk Management and Insurance, University of St. Gallen, 157, 1-45. Retrieved from http://www.ivw.unisg.ch/ /media/internet/content/dateien/ instituteundcenters/ivw/wps/wp157.pdf

Peresetsky, A. A., \& Karminsky, A. M. (2011). Models for moody's bank ratings. Frontiers in Finance and Economics, 1(8), 88-110. Retrieved from http://ssrn.com/abstract=2012447

Poon, W. P. H., Firth, M., \& Fung, H. G. (1999). A multivariate analysis of the determinants of Moody's bank financial strength ratings. Journal of International Financial Markets, Institutions and Money, 9(3), 267-283. https://doi.org/10.1016/S1042-4431(99)00011-6

Royston, P., \& Sauerbrei, W. (2009). Bootstrap assessment of the stability of multivariable models. The Stata Journal, 9(4), 547-570. Retrieved from http://ageconsearch.umn.edu/bitstream/143012/2/sjart_st0177.pdf

Salvador, C., Pastor, J. M., \& De Guevara, J. F. (2014). Impact of the subprime crisis on bank ratings: The effect of the hardening of rating policies and worsening of solvency. Journal of Financial Stability, 11, 13-31. https://doi.org/10.1016/j.jfs.2013.10.005

Scott, L., \& Freese, J. (2006). Regression models for categorical dependent variables using stata. College Station: Stata Press, Texas.

Shen, C. H., Huang, Y. L., \& Hasan, I. (2012). Asymmetric benchmarking in bank credit rating. Journal of International Financial Markets, Institutions and Money, 22(1), 171-193. https://doi.org/10.1016/j.intfin.2011.08.004

Standard \& Poor's. (2011a). Bank spreadsheet data definitions. Criteria | Financial Institutions | Banks, July 5. Retrieved from http://www.standardandpoors.com

Standard \& Poor's. (2011b). Banks: Rating methodology and assumptions. Criteria | Financial Institutions | Banks, Nov. 9. Retrieved from http://www.standardandpoors.com

Van Laere, E., \& Baesens, B. (2011). Analyzing bank ratings: key determinants and procyclicality. Paper presented at the 24th Australasian Finance \& Banking Conference, 14-16 December, Sydney. https://doi.org/10.2139/ssrn.1905443

Van Laere, E., Vantieghem, J., \& Baesens, B. (2012). The difference between Moody's and S\&P bank ratings: is discretion in the rating process causing a split? RMI Working Paper, 12/05, 1-31. Retrieved from http://citeseerx.ist.psu.edu/view doc/download?DOI:10.1.1.730. 7149\&rep=rep1\&type=pdf

Yüksel, S., Dincer, H., \& Hacioglu, U. (2015). CAMELS-based determinants for the credit rating of turkish deposit banks. International Journal of Finance \& Banking Studies, 4(4), 2147-4486. Retrieved from http://www.ssbfnet.com/ojs/index.php/ijfbs/article/view/35/35

\section{Notes}

Note 1. The rating 'all-in' is also called issuer rating or even traditional rating assigned on long-term international scale.

Note 2. Given that our investigation is intended to test the importance of various components in the allocation of the Board with a certain hierarchy [components [factors [variables]]], we use the term 'weights' for the components, the term 'importance' for factors and the term 'relevance' for variables.

Note 3. We will group all bank external factors in the second component.

Note 4. During the revision and the adjustment of its methodology begun in 2007 and widened until 2015, Moody's has removed the external extraordinary supports from the factors of "risks connected to the environment in which operates the bank" to highlight and distributed them in external supports other than systematic (parents, cooperative group and regional government) and systematic support (national government). 
They are incorporated into 'all-in' rating called "issuer Rating 'IR"' as a second component (Damak \& Chichti, 2017). While the ordinary external supports are taken into account in the qualitative sub-factor "operational environment" one of the macro-economic factors and incorporated into the 'stand-alone' rating with the implicit manner in the 2012 methodology revision (Moody's, 2012d) and with an explicit manner in 2015 (Moody's, 2015).

Note 5. The variables used to measure the model CAMEL factors were selected from 29 variables. The choice has been dictated in part by the existing empirical literature (see table 1), and on the other hand, by the results of the regressions of type "stepwise" as performed by Godlewski (2004).

Note 6. S\&P's (2011a) says that they do analytical adjustments to the amounts reported in the financial statements and regulatory filings of the rated entities. These adjustments, in terms of S\&P's, are made to generate measures that are most significant reflections of the economic reality of the financial risks and level differences in reports and facilitate comparisons between institutions and periods which improves the analytical relevance and consistency of the financial ratios used in credit analysis.

Note 7. Similar numerical conversion of ratings have been used by several authors: Salvador et al. (2014), ...

Note 8. We used the Pearson coefficient for CAMEL variables, test Khi-2 for the dummy variables (OC and ACT) and analysis of variance (ANOVA) for mixed variables.

Note 9. The VIF measure the multi-collinearity between the explanatory variables. VIF= 1/(1-R2i) with R2 is the coefficient of determination of the regression of the variable $i$ with the other explanatory variables. A VIF superior to five indicates a strong multi-collinearity.

Note 10. The AIC is a popular measure for comparing maximum likelihood models. AIC $=-2 * \ln ($ likelihood $)+$ $2 * \mathrm{k}$ where $\mathrm{k}=$ number of parameters estimated.

Note 11. The BIF is a way of assessing the degree of stability of the model. The instability of the model occurs when the selected predictors are sensitive to a small change in data (Royston \& Sauerbrei, 2009). The BIF for xj equal $(1 / \mathrm{B}) \sum_{i=1}^{B} I i j$ with $\mathrm{B}=$ number of rows in the result matrix $(\mathrm{B}, \mathrm{k})=$ number of bootstrap sample with size $\mathrm{n}$ and $\mathrm{k}=$ number of variables. Iij take the value 1 if $\mathrm{xj}(\mathrm{j}=1, \ldots, \mathrm{k})$ is selected in the $\mathrm{i}$ th bootstrap sample and 0 if not. The reasonable number of B is 100 to 1000 or more. The BIF is the frequency of the variables used in each sample and could be interpreted as a criterion of the importance of a variable. A variable, which is weakly correlated with others and significant in the complete model must be selected in half of the bootstrap (BIF greater than or equal to 50\%) samples. With the 'p-values' lower, the BIF increases to $100 \%$.

Note 12. We used the stata 12 for all our data treatments.

Note 13. The variables CON/CMP and 'Earnings' variables had negative signs (not expected) in the regressions.

Note 14. With a development level homogeneous sample, the coefficients of the two variable capital origin and bank activity become significant.

\section{Copyrights}

Copyright for this article is retained by the author(s), with first publication rights granted to the journal.

This is an open-access article distributed under the terms and conditions of the Creative Commons Attribution license (http://creativecommons.org/licenses/by/4.0/). 